\title{
A new species of Chaetostoma, an armored catfish (Siluriformes: Loricariidae), from the río Marañón drainage, Amazon basin, Peru
}

\author{
Norma J. Salcedo ${ }^{1}$ and Hernán Ortega ${ }^{2}$
}

A new species of Chaetostoma was found in mountain tributaries of the río Marañon, Peru. The new species differs from all described congeners by having a tuft of odontodes, surrounded by naked skin, in the middle of each trunk lateral dermal plate, and in bearing more than 20 hypertrophied evertible odontodes on three cheek plates vs. evenly distributed odontodes on the whole surface of each dermal plate, and in bearing fewer than 20 hypertrophied evertible odontodes on three cheek plates in all other Chaetostoma species. The new species resembles two Cordylancistrus species in the presence of a tuft of odontodes in the middle of each trunk lateral dermal plate, but it exhibits a naked snout ( $v s$. snout covered with plates in Cordylancistrus) and one uniquely derived character present in some species of Chaetostoma - a short, slender fourth branchiostegal ray.

Una distintiva especie de Chaetostoma fue descubierta en los tributarios de montaña del río Marañón, Perú. La nueva especie se diferencia de todas las otras especies de Chaetostoma descritas por tener un mechón de odontodes, rodeado por piel desnuda, en el medio de cada placa dermal lateral del tronco, y más de 20 odontodes hipertrofiados evertibles en tres placas de la mejilla, en contraste con los odontodes distribuidos de forma homogénea sobre toda la superficie de cada placa dermal lateral del tronco, y menos de 20 odontodes hipertrofiados evertibles en tres placas de la mejilla en las demás especies. La nueva especie se parece a dos especies de Cordylancistrus que exhiben un mechón de odontodes en el medio de cada placa dermal lateral del tronco, pero exhibe un hocico desnudo (vs. hocico cubierto por placas en Cordylancistrus) y un caracter derivado único de algunas especies de Chaetostoma - el cuarto radio branquiostego corto y delgado.

Keywords: Ancistrinae, Andes, Cajamarca, Celendín, mountains.

\section{Introduction}

Chaetostoma Tschudi is one of the most speciose genera within the family Loricariidae. In Peru, members of the genus are commonly found in fast-flowing streams on the northwestern and eastern slopes of the Andes. Chaetostoma was diagnosed by Regan (1904) based on its naked snout without tentacles, wide mouth, short maxillary barbels, and naked ventral surface of head and abdomen. However, Lipopterichthys Norman and Loraxichthys Salcedo also exhibit these traits. Chaetostoma differs externally from Lipopterichthys by having 14 (vs. 12) branched caudalfin rays, from Loraxichthys by having short (vs. long) hypertrophied evertible odontodes on three cheek plates, and from both genera by having an adipose fin (Salcedo, 2013).
In 2005 two specimens collected from the río Sendamal, a tributary of therío Marañón, in Celendín, Peru were brought to our attention. The sample was identified as Chaetostoma due to its naked snout, naked ventral surface of head and abdomen, numerous hypertrophied evertible odontodes on three cheek plates, presence of adipose and anal fins, and 14 branched caudal-fin rays. Other species of Chaetostoma known to inhabit the río Marañón basin are C. branickii Steindachner, 1887 C. breve Regan, 1904 C. dermorhynchum Boulenger, 1887 and C. mollinasum Pearson, 1937. But, unlike any other species of Chaetostoma, the new species exhibits a tuft of odontodes on each dermal plate along the sides of its body. The objective of this paper is to describe this distinct species.

${ }^{1}$ Grice Marine Laboratory, College of Charleston, 205 Fort Johnson, Charleston, SC 29412, USA. salcedon@cofc.edu

${ }^{2}$ Departamento de Ictiología, Museo de Historia Natural, Universidad Nacional Mayor de San Marcos, Apartado 14-0432, Lima 14, Peru. hortega.musm@gmail.com 


\section{Material and Methods}

Counts and measurements follow the methods outlined by Salcedo (2006). Measurements of deformed specimens (e.g. regeneration of parts that compromise landmarks) were not included in the calculation of proportions. Clear and counterstained (c\&s) specimens were prepared following Taylor \& Van Dyke (1985). Osteological nomenclature follows Schaefer (1987). Vertebral and pterygiophore counts were taken from radiographs and c\&s specimens. Vertebral counts include the five Weberian complex centra that precede the first rib-bearing vertebra, and a single complex ural centrum. Abbreviations in the text are standard length (SL) and head length (HL). An asterisk following a meristic value in the description indicates that of the holotype. Number of specimens exhibiting a meristic value is given in parentheses. Institutional codes are as listed in Ferraris (2007).

\section{Results}

\section{Chaetostoma spondylus, new species}

urn:1sid:zoobank.org:act:C09CD002-DCB2-41BE-872ECE099C2B990A.

Fig. 1

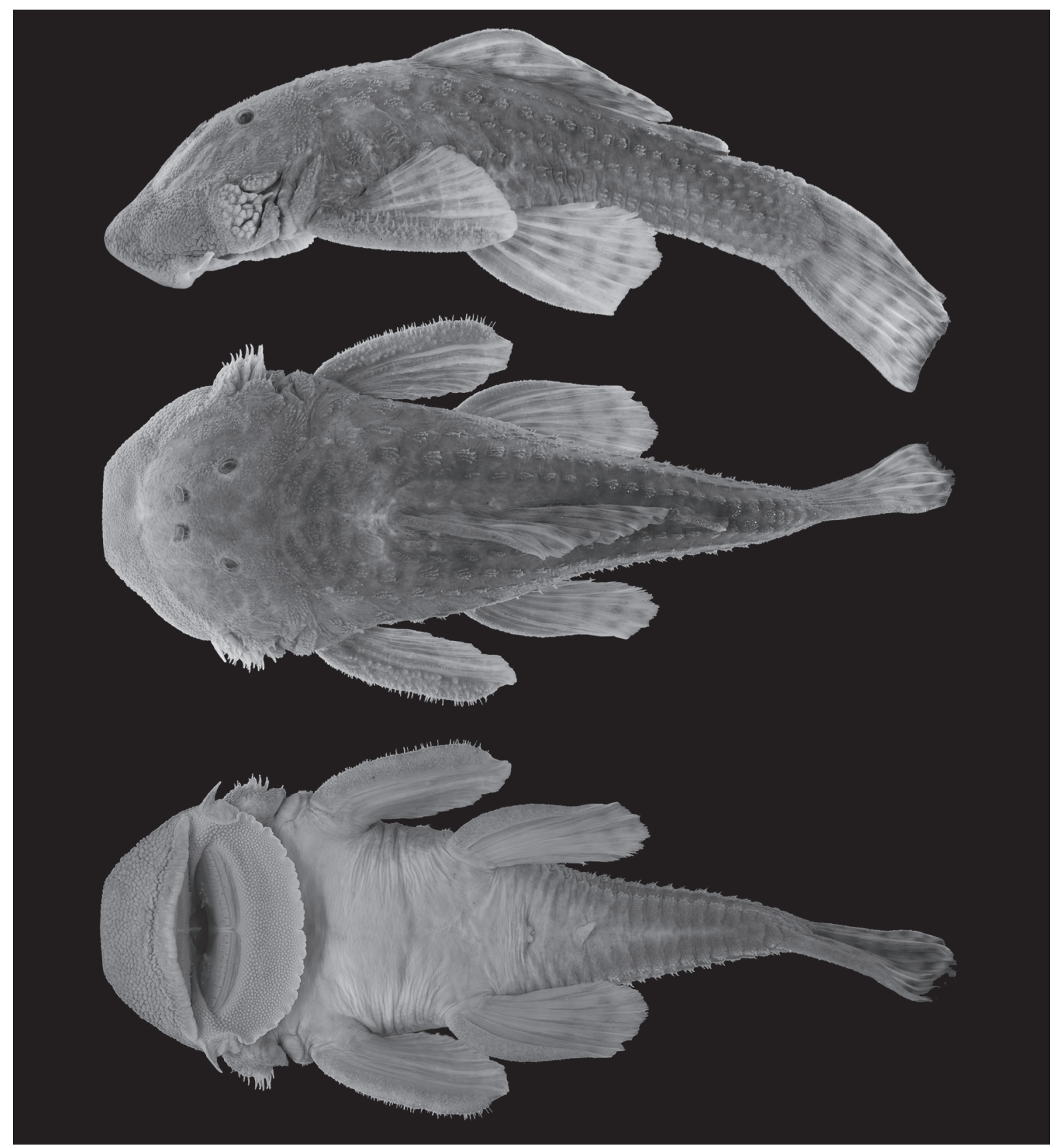

Fig. 1. Chaetostoma spondylus, new species, MUSM 33341, holotype, $119.7 \mathrm{~mm}$ SL, Peru, Departamento de Cajamarca, Celendín, Sorochuco, río Sendamal, tributary of río Marañón, Amazon basin. 
Holotype. MUSM 33341, 119.7 mm SL, Peru, Departamento de Cajamarca, Celendín, Sorochuco, W of Sorochuco, río Sendamal, tributary of río Marañón, 6 61'29.5"S 78 $15^{\prime} 35.2^{\prime \prime} \mathrm{W}, 15$ Oct 2008, D. Lopez.

Paratypes. All from Peru. Departamento de Cajamarca, Celendín, Sorochuco. MUSM 33338, 3, 45.9-115.1 mm SL, 1 c\&s, $100.3 \mathrm{~mm}$ SL, río Churumayo, 6 ${ }^{\circ} 52^{\prime} 15.5^{\prime \prime} \mathrm{S}$ $78^{\circ} 15^{\prime} 23.8^{\prime \prime} \mathrm{W}, 14$ Oct 2008, D. Lopez. MUSM 33339, 1, 101.5 mm SL, río Sendamal, 652’16.2”S 78¹5’18.3”W, 14 Oct 2008, D. Lopez. MUSM 36146, 2, 44.2 and $91.2 \mathrm{~mm}$ SL, río Sendamal, 6 6 51'29.5”'S 78¹5’35.2”W, 22 Jun 2005, P. Golden. Departamento de Cajamarca, Chota, Querocoto. MUSM 40563, 1, $117.6 \mathrm{~mm} \mathrm{SL}$, río Paltic, 6²0’20.2”S 7905'40.4”'W, 17 Jul 2007, R. Eakins. ROM 91081, 1, $121.7 \mathrm{~mm}$ SL, río Paltic, 6²0'20.2”S 7905’40.4”W, 17 Jul 2007, R. Eakins. ROM 91082, 1, 101.5 mm SL, río Paltic, 6²0'08.8'S 79²2'18.5”W, 15 Jan 2008, R. Eakins. Departamento de Piura, Huancabamba, Huancabamba. MUSM 48327, 2, 56.1 and $65.9 \mathrm{~mm} \mathrm{SL}$, quebrada Chula, at mouth into río Huancabamba, $5^{\circ} 15^{\prime} 56.5^{\prime}$ 'S $79^{\circ} 27^{\prime} 38.6$ ”W, 3 Oct 2013, S. A. Schaefer, F. Provenzano \& H. Ortega. MUSM 48328, 2, 51.1 and $85.8 \mathrm{~mm} \mathrm{SL}$, quebrada Chantaco, at bridge Sondor, 5'15'56.5”S $79^{\circ} 25^{\prime} 53.7^{\prime \prime} \mathrm{W}$, 3 Oct 2013, S. A. Schaefer, F. Provenzano \& H. Ortega. Departamento de Amazonas, Chachapoyas, Leimebamba. MUSM 48330, 1, $72.3 \mathrm{~mm}$ SL, río Ollea, at San Francisco del Yeso, 6 ${ }^{\circ} 13^{\prime} 46.4^{\prime \prime}$ S $77^{\circ} 43^{\prime} 55.6^{\prime \prime} \mathrm{W}, 8$ Oct 2013, S. A. Schaefer, F. Provenzano \& H. Ortega.

Diagnosis. Chaetostoma spondylus is distinguished from all other Chaetostoma species by having a tuft of odontodes surrounded by naked skin, in the middle of each trunk lateral dermal plate, and more than 20 hypertrophied evertible odontodes on the three cheek plates $v s$. evenly distributed odontodes on the whole surface of each trunk lateral dermal plate and less than 20 hypertrophied evertible odontodes on the three cheek plates.

Description. Morphometric data in Table 1. Head and body robust. Greatest body width at cleithrum and greater than head length, in specimens longer than $45 \mathrm{~mm}$ SL. Head and body depressed, greatest body depth greater than caudal-peduncle depth. Head profile straight to slightly convex from posterior border of naked snout to posterior border of nasal fossa, straight from posterior border of nasal fossa to posterior border of supraoccipital. Body profile slightly convex from posterior tip of supraoccipital to anterior dorsal-fin base, straight along dorsal-fin base to posterior border of pre-adipose plate, and slightly concave from posterior border of pre-adipose plate to anterior border of caudal fin. Ventral profile of head and body straight in most specimens; convex from posterior margin of cleithrum to pelvic-fin insertion in gravid females. Caudal peduncle trapezoidal in cross-section to anterior border of procurrent caudal-fin rays, triangular with apex dorsally from anterior border of procurrent caudal-fin rays to base of caudal fin. Caudal-peduncle width $88-110 \%$ of caudal-peduncle depth.

Table 1. Proportional measurements of Chaetostoma spondylus, expressed as percents. Range, mean, and standard deviation (SD) based on the holotype and 14 (asterisk) or 15 additional specimens.

\begin{tabular}{lcccc}
\hline & Holotype & range & mean & SD \\
\hline Standard Length (mm) & 119.7 & $44.2-130.9$ & 88.8 & \\
Head length/SL & 35.4 & $31.7-39.8$ & 36.1 & 2.0 \\
Head depth/SL & 19.9 & $18.4-22.5$ & 20.3 & 1.0 \\
Body depth/SL & 22.4 & $19.4-28.1$ & 22.9 & 2.0 \\
Cleithral width/SL & 39.0 & $35.6-41.4$ & 38.5 & 1.7 \\
Interbranchial width/SL & 30.4 & $26.6-32.3$ & 29.7 & 1.8 \\
Pre-dorsal length/SL & 45.7 & $45.7-50.9$ & 47.6 & 1.6 \\
Base of dorsal-fin length/SL* & 24.6 & $19.9-25.7$ & 23.0 & 1.9 \\
First dorsal-fin ray length/SL & 22.4 & $20.7-25.9$ & 23.8 & 1.5 \\
Dorsal-adipose length/SL* & 16.4 & $13.8-19.8$ & 16.0 & 1.7 \\
Pectoral-pelvic length/SL & 23.7 & $20.9-26.3$ & 24.1 & 1.7 \\
Pectoral spine length/SL & 25.4 & $22.0-26.6$ & 24.5 & 1.5 \\
First pelvic-fin ray length/SL & 24.6 & $22.2-27.8$ & 25.4 & 1.7 \\
Interpelvic width/SL & 25.8 & $24.3-27.4$ & 25.9 & 1.0 \\
Pelvic-anal length/SL & 22.5 & $16.6-25.1$ & 23.0 & 2.0 \\
Caudal peduncle length/SL & 26.3 & $24.3-29.4$ & 26.9 & 1.4 \\
Caudal peduncle depth/SL & 12.5 & $11.6-14.8$ & 13.5 & 0.9 \\
Snout length/HL & 68.5 & $63.1-69.6$ & 67.4 & 1.9 \\
Internaris width/HL & 7.0 & $6.5-8.9$ & 7.7 & 0.8 \\
Interorbital width/HL & 27.5 & $25.5-30.7$ & 28.7 & 1.4 \\
Orbit diameter/HL & 9.8 & $7.9-14.5$ & 10.9 & 1.7 \\
Premaxilla length/HL & 28.4 & $25.4-30.3$ & 27.5 & 1.5 \\
Dentary length/HL & 33.4 & $30.0-35.9$ & 32.6 & 1.9 \\
\hline & & & & \\
\hline
\end{tabular}

Body covered dorsally and laterally by plates. Plates with odontodes on most of surface dorsally from posterior border of head, including first mid-ventral plate, to anterior limit of dorsal fin, from posterior border of adipose fin to caudal-fin base, and ventrally from posterior free edge of anal-fin to caudal-fin base. Odontodes on dorsal, middorsal, median, and mid-ventral plate series restricted to middle portion of exposed plate. Plates from anterior limit of dorsal fin to caudal-fin base with tuft of odontodes in one to three rows, with one to five longer odontodes. Pectoralfin spine with enlarged dorsally and dorsolaterally oriented odontodes on dorsal surface. Body naked ventrally from tip of snout to ventral plates posterior to origin of anal fin. Caudal peduncle with coalescent plates ventrally along midline posterior to anal-fin base; first three plates mostly skin covered. 
Dorsal fin with $8(3)$ or $9 *(13)$ rays (one specimen with 6 dorsal rays, with apparently regenerating posteriormost dorsal rays), first ray unbranched. Dorsal-fin base plates $7 *(5)$ or $8(11)$. Pre-adipose plate present* (9) or absent (3). Adipose fin conspicuous. Adipose spine ventrally compressed, blade-like, with dorsal margin transversely rounded. Depressed dorsal fin reaching pre-adipose plate. Plates between dorsal fin and adipose fin 4(3), 5(11), 6*(2). Plates between adipose fin and caudal fin $7(8), 8^{*}(8)$. Anal fin reduced. Anal fin with $1^{*}(1), 2(3), 3(13)$ rays; first ray unbranched. First anal-fin ray with none* (7) to 2(4) or more (1) rows of odontodes. Plates between anal fin and caudal fin 9(6), 10(8), 11*(2). Caudal fin truncated, with two unbranched and 14*(17) branched rays; dorsalmost and ventralmost rays unbranched. Posterior process of cleithrum partially exposed laterally; exposed part of cleithrum narrow, more or less triangular, obliquely oriented, with apex posterodorsally, and straight margins. Pectoral fin with one spine and six branched rays. Pectoral-fin spine strong and reaching to, or slightly beyond, pelvic-fin origin when adpressed. Pelvic fin with one unbranched and five branched rays. First unbranched pelvic-fin ray thick.

Anterior margin of snout rounded in dorsal view. Snout naked, densely covered with conspicuous blister-like, rounded papillae. Dense fat pads present beneath snout skin. Head with shallow ridge, extending from posterior border of naked snout lateral of nasal fossa to anterior border of eye. Head flat dorsally from posterior border of nasal fossa to posterior border of supraoccipital. Oral disk covered by blister-like rounded papillae, smaller than those on snout and not as closely positioned. Posterior lip margin with irregular lobes. Maxillary barbels short, conspicuous. Lateral half of posterior soft surface of each premaxilla with one to five rounded to digitiform papillae. Roof of oral cavity between premaxillae with fleshy digitiform buccal papilla. Anterior surface of dentary with four to ten rounded to digitiform papillae concentrated along twothirds of surface lateral from midline.

Premaxillary teeth in two rows with 47-64 in each row. Dentary teeth in two rows with 51-80 teeth in each row. Always more teeth in dentary than premaxilla. Teeth slender, asymmetrically bifid with tips blunt. Medial tooth cusp twice as long as lateral cusp. Lateral tooth cusp not juxtaposed over medial cusp on premaxillary teeth but slightly juxtaposed over almost full length of medial cusp on dentary teeth.

Hypertrophied evertible odontodes on three cheek plates embedded in soft connective tissue overlaying thick, fleshy flap anterior to opercular flap. Three cheek plates supporting 20 to 42 hypertrophied evertible odontodes. Hypertrophied evertible odontodes with distal tips straight to slightly curved anteriorly. Exposed part of opercle triangular, its free border with one or two rows of enlarged odontodes with distal tips straight to slightly curved posteriorly. Small opercular opening covered by fleshy opercular flap, bordered posteriorly by exposed cleithrum.
Infraorbital sensory canal extending beyond anterior border of first infraorbital canal-bearing plate. First infraorbital plate with laminar projections. Second infraorbital plate two to three times larger than first infraorbital. Third infraorbital plate situated along lateral rim of nasal fossa. Fourth through sixth infraorbital plates along anterolateral margin of orbit. Nasal plate long tube with no laminar projections. Frontal large and elongated, along posteromedial rim of nasal fossa and medial margin of orbit. Sphenotic rectangular, with wide lateral projection in contact with sixth infraorbital plate along posteromedial margin of orbit. Pterotic-supracleithrum not in contact with posterior margin of orbit. Suprapreopercle with wide lateral projections. Suprapreopercle in contact with sixth infraorbital plate.

Lateral line extending from posterior border of pteroticsupracleithrum to median plate at caudal-fin base or one immediately anterior. Lateral-line plates 23(1), 24(6), or $25^{*}(10)$. First lateral-line plate in form of simple tube with narrow laminar expansions and embedded in skin. Second lateral-line plate one-half size of third median plate. Third lateral-line plate about same size as fourth plate.

Vertebrae $28^{*}(5)$ or $29(1)$. Nine ribs (6). First rib thick and articulating directly to sixth centrum, second rib articulating to eighth centrum. Epural blade-like, separated from fused hypurals (hypurals 3-5 + uroneural), articulating dorsally to base of posteriormost procurrent rays and not reaching $27^{\text {th }}$ and $28^{\text {th }}$ centra ventrally (1).

Nuchal plate completely covered by bony plates and skin. First dorsal-fin spinelet completely covered by skin. Dorsal fin supported by nine pterygiophores (1), with first pterygiophore articulating with neural spine of seventh vertebra. Anal fin supported by $1 *(3)$ or 2(2) pterygiophores (fused proximal and medial radials), with first pterygiophore contacting hemal spine of fifteenth vertebra.

Color in alcohol. Head and body brown dorsally. Body yellowish-brown ventrally. Irregular dark blotches present on body. Blotches ranging from rounded to narrow bands and noticeable on most specimens. Black spot present on base of membrane between first unbranched and first branched dorsal-fin rays. Dark brown first dorsal-fin ray followed by three to five (rarely six) dark bars on each dorsal-fin ray. Membranes with faint pigmentation mostly proximate to pigmented area on branched rays in specimens of SL>50 mm. One to three dark bars on first dorsal-fin ray and on each branched dorsal-fin ray, membranes not pigmented in specimens of $\mathrm{SL}<50 \mathrm{~mm}$. Caudal fin with four to six (rarely three or seven) dark bars on each ray. First bar on posterior margin of elongated plates at base of caudal fin. Anal fin with two or three dark bars; bars faint in some specimens. Pectoral-fin spine and rays coloration between six brown bars and overall brown with narrow light bars dorsally. Pectoral-fin membranes pigmented in most specimens. Pectoral fin light-brown ventrally. Pelvic-fin rays with four to six brown bars dorsally along 
their lengths, membranes pigmented along border of rays. Pelvic fin light-brown ventrally. Ventral plates of caudal peduncle brown.

Color in life. Body with greenish-brown ground color. Head with irregular dark blotches, about size of eye. Large dark blotches, twice size of eye, on plates between posterior border of head and anterior border of dorsal-fin origin. Body plates with large, irregular dark markings. Pectoral-fin and pelvic-fin membranes light red dorsally. Pectoral and pelvic fin-rays and membranes light red ventrally. Oral disk pinkish-brown. Body yellowish-white where naked. Plates ventrally dark brown on greenish-brown background.

Sexual dimorphism. None detected. All specimens have no fold to shallow fleshy fold along dorsomedial border of first pelvic-fin ray.

Distribution. Río Chotano, río Huancabamba, río Sendamal, and río Utcubamba, mountain tributaries (1500$2000 \mathrm{~m}$ above sea level) of río Marañón, Amazon River basin, Peru (Fig. 2).

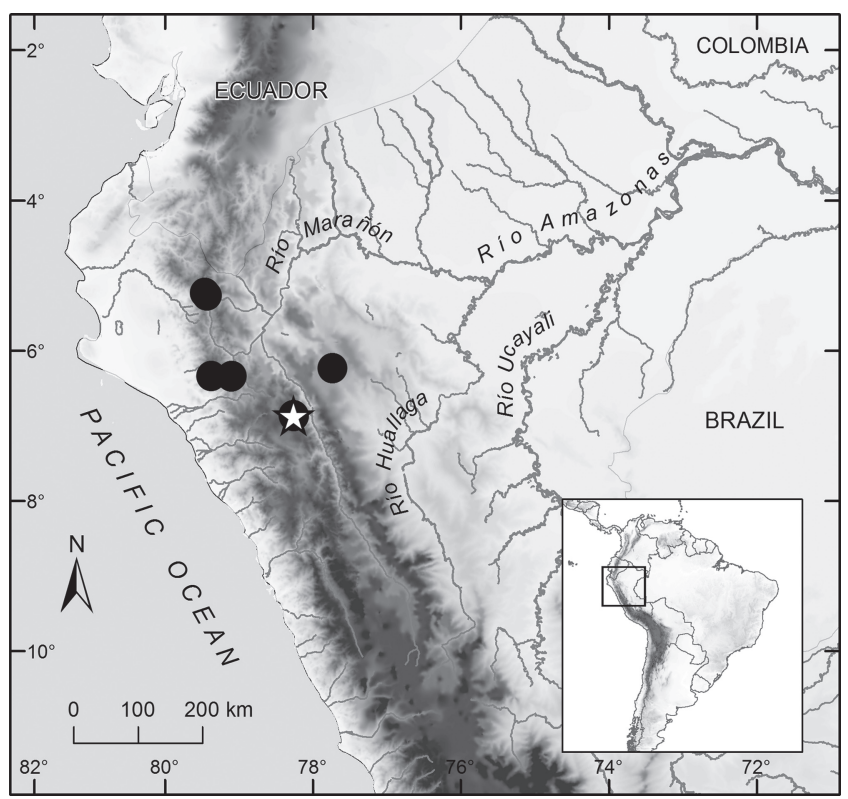

Fig. 2. Geographic distribution of Chaetostoma spondylus. Symbols represent more than one lot, and more than one locality. Star indicates type locality.

Ecological notes. Based on the habitat description by Robert Eakins, who collected several specimens in the río Paltic. Species occurs in high gradient stream and rapids, over mostly boulder substrate. Waters highly oxygenated $(8.2 \mathrm{mg} / \mathrm{L})$ with almost neutral $\mathrm{pH}(7.1)$.

Etymology. The specific name, spondylus, is in reference to the tuft of odontodes on the trunk lateral dermal plates that resemble the thorny projections of the bivalve mollusk known as spiny oyster. A noun in apposition.

\section{Discussion}

Chaetostoma spondylus shares one synapomorphy with C. loborhynchos Tschudi, 1846, C. marmorescens Eigenmann \& Allen, 1942 and C. mollinasum, the presence of a short, slender fourth branchiostegal ray, in contrast to the long, distally wide ray in all other studied species of Chaetostoma. The fourth branchiostegal ray is absent in C. taczanowskii Steindachner, 1882 (Salcedo, 2003). These species, including C. tacznowskii, also share the presence of conspicuous blister-like rounded papillae, densely packed on the naked snout, and more than nine hypertrophied evertible odontodes on three cheek plates.

Chaetostoma spondylus is the fifth species of Chaetostoma described from tributaries of the río Marañón. Chaetostoma breve and C. dermorhynchum are known from northern tributaries; and $C$. branickii and $C$. mollinasum from southern tributaries of the basin. Of these species, C. breve, C. dermorhynchum, and C. branickii exhibit less than nine hypertrophied evertible odontodes with hooked tips on three cheek plates, in contrast to more than nine hypertrophied evertible odontodes with straight to slightly curved tips on three cheek plates in $C$. mollinasum and C. spondylus.

The tufts of odontodes on the trunk lateral dermal plates of Chaetostoma spondylus at first resemble the "keeled plates" pattern in Acanthicus Spix \& Agassiz, Leporacanthicus Isbrücker \& Nijssen, Megalancistrus Isbrücker, and Pseudacanthicus Bleeker (Armbruster, 2004; Ballen \& Vari, 2012), in which some odontodes in the middle of the plate are more developed and project past the posterior border of each plate. The plates of Chaetostoma spondylus are, however, mostly flat with the ventral series of plates gently curved in the middle and not forming keels. Each body plate is mostly covered by skin. The tuft of developed odontodes in the middle of the plate is the trait that gives a keeled aspect to some plate series of C. spondylus.

In addition to Chaetostoma spondylus, two species of closely related loricariids exhibit a patchy pattern of developed odontodes surrounded by naked areas: Cordylancistrus platycephalus (Boulenger) and an undescribed species of Cordylancistrus from northern Peru (Hemiancistrus platycephalus in Salcedo, 2003). Both species differ externally from C. spondylus by the presence of plates on the anterior border of the snout and the wide, truncated, posterior border of the exposed cleithrum, $v s$. absence of plates on the snout and a narrow, dorsally tapered, posterior border of the exposed cleithrum in C. spondylus. Furthermore, the lack of odontodes on part of the plates has been reported for Neoplecostomus bandeirante Roxo, Oliveira \& Zawadzki and N. botucatu Roxo, Oliveira \& Zawadzki as naked areas between plates (Roxo et al., 2012), which based on ongoing phylogenetic studies by the first author, is a homoplasy shared with Chaetostoma spondylus, Cordylancistrus platycephalus, and the undescribed Cordylancistrus species from northern Peru. 
Comparative Material. Chaetostoma loborhynchos. Peru. NMW 47190, 1, holotype (photographs), $120.2 \mathrm{~mm} \mathrm{SL}$, río Tulumayo. MUSM 20288, 1, 99.0 mm SL, río Tulumayo. MUSM 20291, 5, 85.5-120.3 mm SL, 1 c\&s, 72.3 mm SL, río Tulumayo. MUSM 20289, 3, 91.4-141.8 mm SL, río Paucartambo. MUSM 20307, 6, 80.2-121.2 mm SL, río Paucartambo. Chaetostoma branickii. Peru. MUSM 12567, 3, 115.6-131.9 mm SL, río Chotano. Chaetostoma marmorescens. Peru. USNM 167884, 10, 41.3-133.4 mm SL, Huancachupa creek. Chaetostoma mollinasum. Peru. CAS 64653, 8, syntypes, 28.2-54.6 mm SL, Balsas. CAS 64654, 5, syntypes, 30.3-41.2 mm SL, Cajamarca. MUSM 5148, 2 c\&s, 46.1 and $51.8 \mathrm{~mm}$ SL, río Huancabamba. Chaetostoma taczanowskii. Peru. MUSM 5186, 1 c\&s, $65.4 \mathrm{~mm}$ SL, río Huayabamba. MUSM 5191, 2, 97.9 and 116.9 mm SL, río Huayabamba. Cordylancistrus platycephalus. Ecuador. LACM 57394, 2, 72.7 and $79.3 \mathrm{~mm}$ SL, río Tutanangoza. Cordylancistrus sp. Peru. MUSM 6131, 1, 84.7 mm SL, río Comainas. MUSM 6139, 1, 85.7 mm SL, río Comainas. MUSM 6142, 3, 47.3-110.5 mm SL, 1 c\&s, 77.9 mm SL, río Comainas. MUSM 6162, 1, 76.1. MUSM 6176, 1, 136.6 mm SL, río Comainas. MUSM 6177, 1, $109.2 \mathrm{~mm}$ SL, río Comainas.

\section{Acknowledgements}

Thanks to Antony S. Harold (GML) for access to facilities and assistance with radiographic equipment, to Scott A. Schaefer and Barbara Brown (AMNH) for hospitality and access to facilities while visiting the collections, and to Robert J. Eakins (EcoMetrix Inc.) for providing photographs of freshly caught specimens and field notes. We thank Jonathan W. Armbruster and David Werneke (AUM), Rick Feeney (LACM), Erling Holm (ROM) for the loan of specimens, and Mahmoud Mehanna (LBP-UNESP) and Alex Urbano-Bonilla (PUJ) for help in obtaining needed literature. This is contribution number 427 of the Grice Marine Laboratory.

\section{References}

Armbruster, J. W. 2004. Phylogenetic relationships of the suckermouth armoured catfishes (Loricariidae) with emphasis on the Hypostominae and the Ancistrinae. Zoological Journal of the Linnean Society, 141: 1-80.

Ballen, G. A. \& R. P. Vari. 2012. Review of the Andean armored catfishes of the genus Dolichancistrus Isbrücker(Siluriformes: Loricariidae). Neotropical Ichthyology, 10: 499-518.

Boulenger, G. A. 1887. An account of fishes collected by Mr. C. Buckley in eastern Ecuador. Proceedings of the Zoological Society of London (Part 2): 274-283.
Eigenmann, C. H. \& W. R. Allen. 1942. Fishes of Western South America. I. The Intercordilleran and Amazonian lowlands of Peru. II. The High Pampas of Peru, Bolivia, and Northern Chile. With a revision of the Peruvian Gymnotidae, and of the genus Orestias. The University of Kentucky, Lexington, 1-494.

Ferraris Jr., C. J., 2007. Checklist of catfishes, Recent and fossil (Osteichthyes: Siluriformes), and catalogue of siluriform primary types. Zootaxa, 1418: 1-628.

Pearson, N. E. 1937. The fishes of the Atlantic and Pacific slopes near Cajamarca, Peru. Proceedings of the California Academy of Sciences (Ser. 4), 23: 87-98.

Regan, C. T. 1904. A monograph of the fishes of the family Loricariidae. Transactions of the Zoological Society of London, 17: 191-350.

Roxo, F. F., C. Oliveira \& C. H. Zawadzki. 2012. Three new species of Neoplecostomus (Teleostei: Siluriformes: Loricariidae) from the upper Rio Paraná basin of southeastern Brazil. Zootaxa, 3233: 1-21.

Salcedo, N. J. 2003. Análisis Filogenético del género Chaetostoma Tschudi, 1845 (Siluriformes: Loricariidae), con énfasis en especies Peruanas. Unpublished Master's Thesis, Universidad Nacional Mayor de San Marcos, Lima, 150p.

Salcedo, N. J. 2006. New species of Chaetostoma (Siluriformes: Loricariidae) from Central Peru. Copeia, 2006: 60-67.

Salcedo, N. J. 2013. Description of Loraxichthys lexa, new genus and species (Siluriformes: Loricariidae) from the Río Huallaga Basin, central Peru, with notes on the morphology of the enigmatic Lipopterichthys carrioni Norman, 1935. Zootaxa, 3640: 557-571.

Schaefer, S. A. 1987. Osteology of Hypostomus plecostomus (Linnaeus), with a phylogenetic analysis of the loricariid subfamilies. Contributions in Science, Natural History Museum of Los Angeles County, 394: 1-31.

Steindachner, F. 1881. Beiträge zur Kenntniss der Flussfische Südamerika's. II. Denkschriften der MathematischNaturwissenschaftliche Classe der Kaiserlichen Akademie der Wissenschaften, 43: 103-146.

Steindachner, F. 1882. Beiträge zur Kenntniss der Flussfische Südamerika's. IV. Anzeiger der Kaiserlichen Akademie der Wissenschaften. Mathematisch-Naturwissenschaftliche Classe, 19: 175-180.

Taylor, W. R. \& G. C. Van Dyke. 1985. Revised procedures for staining and clearing small fishes and other vertebrates for bone and cartilage study. Cybium, 9: 107-119.

Tschudi, J. J. 1846. Ichthyologie. Pp.1-35. In: Tschudi, J. J. 184446. Untersuchungen über die Fauna Peruana. Scheitlin \& Zollikofer, St. Gallen.

Submitted May 15, 2014

Accepted December 2, 2014 by Paulo Lucinda

Published March 31, 2015 